\title{
The Possible Relationship between Mathematical Skills and Vocal Performance
}

\section{A possível relação entre habilidades matemáticas e desempenho vocal}

\author{
(iD) Wanli Hu \\ Conservatory of Music, Huanghuai University, Zhumadian City, Henan Province, China \\ wanlihu44@yahoo.com, zjkhy@vip.qq.com
}

\begin{abstract}
The purpose of this study was to verify a possible relationship between vocal performance and mathematical skills. The study has polled 60 vocal students and 6 voice teachers, analysed educational records, and conducted an independent singing examination. Using the Student's t-test, it was found that vocal performance estimates carried among student with different levels of mathematical competency indicated a connection between vocal performance and mathematical abilities. The results revealed that vocal students with relatively well-developed mathematical skills outperformed those with poor mathematical abilities by around 33 percentage points.
\end{abstract}

Keywords: connection between music and math; mathematical skills; music performance; vocal skills; vocal performance.

Resumo: O objetivo deste estudo foi verificar uma possível relação entre desempenho vocal e habilidades matemáticas. O estudo entrevistou 60 estudantes de canto e 6 professores de canto, analisou registros educacionais e conduziu um exame independente de canto.

\footnotetext{
1 Hu Wanli (1975 -), Associate Professor of Conservatory of Music of Huanghuai University, Master of vocal music singing and teaching research of Conservatory of Music of Hangzhou Normal University, Ph.D. in music performance of Philippine Sao Paulo University (Manila). The author has two books, published 16 articles in core journals, presided over and participated in 12 provincial and ministerial projects. He has won the special prize and the first prize in the provincial teaching competition for many times.
} 
Por meio do teste-t de Student, verificou-se que as estimativas de desempenho vocal realizadas entre alunos com diferentes níveis de competência matemática indicaram uma relação entre desempenho vocal e habilidades matemáticas. Os resultados revelaram que os alunos vocais com habilidades matemáticas relativamente bem desenvolvidas superaram aqueles com habilidades matemáticas fracas em cerca de 33 pontos percentuais.

Palavras-chave: conexão entre música e matemática; habilidades matemáticas; performance musical; habilidades vocais; desempenho vocal.

Submetido em: 11 de fevereiro de 2021

Aceito em: 9 de março de 2021 
The Possible Relationship between Mathematical Skills and Vocal Performance Wanli Hu

\section{Introduction}

The link between musical abilities of a person and his/her penchant for mathematics is a promising interdisciplinary research topic, which currently gains popularity (GORE and HAYNES, 2020; MONTIEL and GÓMEZ, 2014; VAUGHN, 2000; SCHELLENBERG, 2016; SHCHEDRINA et al., 2020). The overwhelming majority of studies show that students who are good at exact sciences also perform better in the music classroom when compared to those struggling with the basic math problems (JONES and PEARSON, 2013; MCDONEL, 2015). A qualitative survey of 24 learners carried out to establish a connection between musical and mathematical abilities revealed that a significant portion of respondents were certain that knowledge of mathematics was crucial for a better understanding of music theory (CRANMORE and TUNKS, 2015a, 2015b), especially rhythm-related concepts. HAMILTON et al. (2018) discovered a similar tendency. In particular, a correlation was found between one's understanding of rhythm and proficiency in mathematical concepts, such as fractions, equivalence, and division. The research showed that bringing music into the mathematics classroom enabled students to better absorb information. However, an inverse correlation is also possible (BOCCARDI, 2015; DA SILVA, 2019; TISDELL, 2019). A pretest-posttest research on high school students revealed that incorporating music with mathematics lesson improves learning performance significantly (AN and TILLMAN, 2015; AN et al., 2015). More recent studies report similar results (HOLMES and HALLAM, 2017; PERGER et al., 2018). BERGEE and WEINGARTEN (2020), for example, found that training schoolchildren with music has significantly improved their mathematical and reading skills. The methodology they used was based on a four-level model, designed to analyze the performance of individual students, classrooms, schools, and districts. The results were obtained with the help of two music achievement tests. 
The Possible Relationship between Mathematical Skills and Vocal Performance Wanli Hu

It should be noted that issues surrounding the integration of music and mathematics in the classroom have been well studied, and evidences on the positive correlation between musical and mathematical abilities have been around for a long time (EDELSON and JOHNSON, 2003; MANTHEI and KELLY, 1999). Music was found to have a positive impact on one's cognitive abilities and health. For example, Weinberger (1998) emphasizes that music has beneficial effects on brain development and even enhances reading and mathematics skills. Furthermore, music has a strong impact on the brain. For instance, individuals who listen to music speed up the transmission of nerve impulses through synapses. This is conducive to creativity, high self-esteem, and social integration (TŠUIKINA and BUSURINA, 2020). Listening to music also has the potential to significantly affect intelligence (KERSTEN, 2014; SWAMINATHAN and SCHELLENBERG, 2018; WINTER, 2016). Another work investigated the effects of piano keyboard training on the spatial-temporal development of preschool children (GRAZIANO et al., 1999). The results showed that children given piano keyboard lessons were better at learning fractions and proportional math than children not engaged in musical activity. These results are consistent with the previous studies (HAMILTON et al., 2018). It should be noted that mathematical concepts, such as fractions and proportional math, pose a challenge to the vast majority of students and are difficult to explain (BAKER, 2011). From a physiological point of view, the positive correlation that has been found between music and mathematical reasoning may be associated with the ability of music to influence processes in the cerebral cortex.

However, a meta-analysis of the studies investigating the impact of music training on cognitive development of children failed to find any evidence in the favor of a positive effect (SALA and GOBET, 2017). Despite the existence of many articles reporting a beneficial effect of music on cognitive development (BARBAROUX et al., 2019; HABIBI et al. 2019), RICKARD et al. (2012) also failed to associate music with improvements in visual memory, verbal memory, and visual-spatial reasoning. As it can be seen, there 
The Possible Relationship between Mathematical Skills and Vocal Performance Wanli Hu

are many conflicting studies and different perspectives regarding the transfer of music skills to non-music ones, such as verbal memory, academic performance, spatial-temporal reasoning, etc. (MIENDLARZEWSKA and TROST, 2013).

This work examines the vocal performance of the respondents with respect to their academic achievements in the exact sciences. It is hypothesized that students with well-developed mathematical skills exhibit better vocal performance than students with poorly developed mathematical skills.

\section{Materials and Methods}

This study used a poll research approach to collect data from two groups of respondents, namely vocal students (vocalists) and their voice teachers. The study sought to compare the students' perceptions regarding vocal performance and independent examination scores in music and mathematics classes. As a result, the study involved six independent, normally-distributed data sets.

Sixty first-year students majoring in vocal performance were sampled for a homogenous research design. No regard was given to age, gender, and nationality. All recruits had only attained secondary school education. The students were divided into two groups of mathematical ability: (1) those with well-developed mathematical skills (math group), and (2) those with poorly developed ones (non-math). The sorting procedure involved giving respondents the school-level mathematical tasks to solve. The study involved 6 voice teachers.

There were several steps involved in finding a correlation between vocal performance and mathematical abilities. The first was asking the students to rate their vocal performance on a scale of 1 to 10 . The second was asking voice teachers to evaluate achievements of their students on a similar scale from 1 to 10 . Then, in step 3, students' grades from the previous semester 
The Possible Relationship between Mathematical Skills and Vocal Performance Wanli Hu

were analyzed. The results were converted to a 10-point scale. After the poll, students were asked to sing two classical songs in front of two independent examination commissions (steps 4 and 5 , respectively). Scores for the singing exam were given by the independent examination commission through voting. Each student could score in the range from 1 to 10 . Finally, the average group scores were found. Data were checked for normality using the Shapiro-Wilk test. For this, the following formula was employed:

$$
W=\frac{1}{s^{2}}\left[\sum_{i=1}^{n} a_{n-i+1}\left(x_{n-i+1}-x_{i}\right)\right]^{2},
$$

where represents variance; are equal to 0.6646 and 0.1677 ; $x$ is the value of the data; $n$ is the sample size; and $i$ a variable that can take the values 1 or 2 . Differences between data sets were found using the Student's t-test. For this, the following formula was used:

$$
t=\frac{\overline{x_{1}}-\overline{x_{2}}}{s}
$$

where is the average value of the sample "Math", is the average value of the sample "Non-Math", $s$ is the square root of the variance. Differences were considered statistically significant at $p<0.05$.

\section{Results and Discussion}

Average scores collected at each step of the study are depicted in Table 1. Numbers in column 1 correspond to research steps. Hence, the first three rows contain polling results and retrospective data on vocal performance. Rows four and five present averaged 
The Possible Relationship between Mathematical Skills and Vocal Performance Wanli Hu

examination estimates. Columns 2 and 3 present average group scores for math and non-math groups.

Table 1. Averaged vocal performance scores among first-year vocal students

\begin{tabular}{|l|l|l|}
\hline No. & Math & Non-Math \\
\hline 1 & 8.67 & 5.98 \\
\hline 2 & 9.03 & 6.31 \\
\hline 3 & 8.89 & 5.67 \\
\hline 4 & 8.55 & 6.11 \\
\hline 5 & 9.09 & 5.69 \\
\hline
\end{tabular}

As can be seen in Table above, the first group scored in the range from 8.55 to 9.09 points, that is, around 9 points in all steps, whereas the second, group with its 6 points, scored slightly lower. Furthermore, students' subjective perception of their own vocal performance was slightly lower when compared to teachers' opinions and consistent with grades they received in the previous semester. However, students' perceptions regarding vocal performance in the first group were slightly lower than their actual performance. On the other hand, students with relatively poor mathematical skills had higher perceptions of their own performance in the signing class than the actual performance estimates.

The independent exam scores are ambiguous within the samples. The average group score given by the first examination commission is lower than the actual performance score obtained in the classroom. At the same time, the second examination commission marked the vocal skills of students in the first group rather high, such that the resultant average group score turned out to be much higher than the overall students' perception, the overall teachers' perception, and the average group score from the previous semester. The second group, however, scored lower when compared to students' and teachers' perceptions, but the average group score was consistent with the past achievement. 
The Possible Relationship between Mathematical Skills and Vocal Performance Wanli Hu

Factors that have influenced the examiners' decision-making are unknown.

Table 2 shows the results of the normality test. The first row contains the average values of the samples, whilst the second and third rows depict data on variance and sample size, respectively. Rows four and five present empirical and tabular values of normality.

Table 2. Results of the Shapiro-Wilk test

\begin{tabular}{|lll|}
\hline \multicolumn{3}{|c|}{ Shapiro-Wilk } \\
\hline & Math & Non-Math \\
\hline$<x>$ & 8.846 & 5.952 \\
\hline$s^{2}$ & 0.5677 & 0.30208 \\
\hline$n$ & 5 & \\
\hline W & 0.069502 & 0.1694913 \\
\hline Wcr & 0.928 & \\
\hline
\end{tabular}

As it can be seen in Table above, the empirical value of normality is larger than the tabular one, which indicates that samples follow the normal distribution. In addition, the sample size is greater than 4. Hence, the t-test can be performed.

Table 3 presents the results of the Student's t-test. Rows one and two depict data on variance and sample size, respectively, and rows three and four present empirical and tabular t-values, respectively. The t-test was aimed at testing the research hypothesis. In this case, if the calculated t-value is greater than the tabular one, then it (research hypothesis) is proved. Otherwise, it is rejected. 
The Possible Relationship between Mathematical Skills and Vocal Performance Wanli Hu

Table 3. Results of the t-test

\begin{tabular}{|ll|}
\hline \multicolumn{2}{|l|}{ Student's t-test } \\
\hline $\mathrm{s}^{2}$ & 0.217445 \\
\hline $\mathrm{n}$ & 5 \\
\hline $\mathrm{t}$ & 6.206172 \\
\hline $\mathrm{tcr}$ & 2.776 \\
\hline
\end{tabular}

Based on the results of the t-test, the research hypothesis can be considered proved. As it can see in Table 2, the average scores of the math group are significantly higher than those of the non-math one. This suggests that there is a positive correlation between one's mathematical abilities and his/her musical (in this case, vocal) skills.

The connection between mathematics and music has been well studied (CAPOZUCCA and FERMANI, 2019; ELOFSSON et al., 2016; MAYES, 2018). A survey of 68 university students in Spain revealed that musical exercises significantly affect one's performance in the mathematics classroom (CHAO-FERNÁNDEZ et al., 2017). In particular, there was a positive correlation between music training and cognitive abilities of the respondents. A similar study was carried out among elementary school students (ROA et al., 2020). It was found that music training had a beneficial effect on STEAM learning. However, those results do not fully agree with earlier studies. This may indicate that a certain dependence between learning performance and learning context is present. A similar methodology was used in a range of other studies (S. ACAN and N. ACAN, 2019; ANDREOTTI and FRANS, 2019; MANNONE, 2019). Other scholars explore Mathematical Music Theory and Mathematical Music Game (MAZZOLA, 2017).

It should be noted that a direct correlation between vocal performance and mathematical abilities is rather poorly studied. The authors of this article failed to find any reliable information about this sort of connection between mathematical and vocal 
The Possible Relationship between Mathematical Skills and Vocal Performance Wanli Hu

skills. Nevertheless, GUHN et al. (2020) explored the association between vocal performance and achievements in mathematics and science. The results, however, are not in agreement with the present findings.

\section{Conclusions}

This work was aimed to find association between vocal skills and mathematical abilities. The results show that vocal students with relatively well-developed set of mathematical skills outperformed those with poor mathematical abilities by around 33 percentage points. Based on the Student's t-test results, it was established that strong mathematical competence is conducive to higher vocal performance. The present work can serve as a platform for similar studies. The limitation of this research is a small sample size, which can affect the accuracy of the results. Hence, a study with a larger number of respondents and assessment methods is recommended. The results of the study may be used to substantiate the integration of musical (vocal) and mathematical classes for learning enhancement.

\section{References}

ACAN, Sinan Can, ACAN, Naciye Leyla. Music notes to amino acid sequence: A STEAM approach to study protein structure. Biochemistry and Molecular Biology Education, v. 47, n. 6, p. 669-671, 2019.

AN, Song A., TILLMAN, Daniel A. Music Activities as a Meaningful Context for Teaching Elementary Students Mathematics: A QuasiExperiment Time Series Design with Random Assigned Control Group. European Journal of Science and Mathematics Education, v. 3, n. 1, p. 45-60, 2015. 
The Possible Relationship between Mathematical Skills and Vocal Performance Wanli Hu

AN, Song, TILLMAN, Daniel, PAEZ, Carlos. The Effects of Interdisciplinary Practice on Elementary Preservice Teachers' Mathematics Teaching Self-Efficacy and Pedagogy: An Intervention Study of Music-Mathematics Integrated Education. Journal of Mathematics Education at Teachers College, v. 6, n. 1, p. 9-24, 2015. ANDREOTTI, Erica, FRANS, Renaat. The connection between physics, engineering and music as an example of STEAM education. Physics Education, v. 54, n. 4, p. 045016, 2019.

BAKER, Alan. Explaining the applicability of mathematics in science. Interdisciplinary Science Reviews, v. 36, n. 3, p. 255-267, 2011.

BARBAROUX, Mylène, DITTINGER, Eva, BESSON, Mireille. Music training with Démos program positively influences cognitive functions in children from low socio-economic backgrounds. PLOS ONE, v. 14, n. 5, p. e0216874, 2019.

BERGEE, Martin J., WEINGARTEN, Kevin M. Multilevel Models of the Relationship between Music Achievement and Reading and Math Achievement. Journal of Research in Music Education, v. 1, p. 0022429420941432, 2020.

BOCCARDI, Amanda. Math is Music to Our Ears: The Effects of a Music and Movement Integrated Mathematics Curriculum on Second Grade Students' Engagement with Learning. [Undergraduate Senior Thesis] Newark: University of Delaware, 2015. 142 p.

CAPOZUCCA, Andrea, FERMANI, Marco. Make Music Visible, Play Mathematics. In: Bridges 2019 Conference Proceedings. Phoenix: Tessellations Publishing, 2019. p. 647-650.

CHAO-FERNÁNDEZ, Rocío, ROMÁN-GARCÍA, Sara, CHAO-FERNÁNDEZ, Aurelio. Art, Science and Magic: Music and Math the classroom. TEEM 2017: Proceedings of the 5th International Conference on Technological Ecosystems for Enhancing Multiculturality, 2017. CRANMORE, Jeff, TUNKS, Jeanne. Brain Research on the Study of Music and Mathematics: A Meta-Synthesis. Journal of Mathematics Education, v. 8, n. 2, p. 139-157, $2015 a$. 
The Possible Relationship between Mathematical Skills and Vocal Performance Wanli Hu

CRANMORE, Jeff, TUNKS, Jeanne. High School Students' Perceptions of the Relationship between Music and Math. Mid-Western Educational Researcher, v. 27, n. 1, p. 51-69, 2015b.

DA SILVA, Ricardo Scucuglia Rodrigues. On music production in mathematics teacher education as an aesthetic experience. ZDM, v. 52, p. 973-987, 2019.

EDELSON, R. Jill, JOHNSON, Gretchen. Music Makes Math Meaningful. Childhood Education, v. 80, n. 2, p. 65-70, 2003.

ELOFSSON, Jessica, BOHM, Anna Englund, JEPPSSON, Catarina, SAMUELSSON, Joakim. Physical activity and music to support preschool children's mathematics learning. International Journal of Primary, Elementary and Early Years Education, v. 46, n. 5, p. 483-493, 2016.

GORE, Dalton, HAYNES, Phillip. The Impact of Music on Human Cognition on Mathematical Assessments. Journal of Psychology, v. 2, n. 1, p. 1-10, 2020.

GRAZIANO, Amy B., PETERSON, Matthew, SHAW, Gordon L. Enhanced learning of proportional math through music training and spatialtemporal training. A Journal of Progress in Neurosurgery, Neurology and Neurosciences, v. 21, n. 2, p. 139-152, 1999.

GUHN, Martin, EMERSON, Scott D., GOUZOUASIS, Peter. A populationlevel analysis of associations between school music participation and academic achievement. Journal of Educational Psychology, v. 112, n. 2, p. 308-328, 2020.

HABIBI, Assal, DAMASIO, Antonio, ILARI, Beatriz, SACHS, Matthew Elliott, DAMASIO, Hanna. Music training and child development: a review of recent findings from a longitudinal study. Annals of the New York Academy of Sciences, v. 1423, n. 1, p. 73-81, 2019.

HAMILTON, Tara Julia, DOAI, Julieanne, MILNE, Andrew, SAISANAS, Vicky, CALILHANNA, Hilton, COURTNEY, Andrea, GOLDWATER, Micah, COHN, Richard. Teaching Mathematics with Music: A Pilot Study. In: IEEE International Conference on Teaching, Assessment, and Learning for Engineering (TALE). Wollongong, NSW, Australia, 2018. p. 927-931. 
The Possible Relationship between Mathematical Skills and Vocal Performance Wanli Hu

HOLMES, Sylwia, HALLAM, Susan. The impact of participation in music on learning mathematics. London Review of Education, v. 15, n. 3, p. 425-438, 2017.

JONES, Shelly M., PEARSON, Dunn. Music: Highly Engaged Students Connect Music to Math. General Music Today, v. 27, n. 1, p. 18-23, 2013.

KERSTEN, Luke. Music and Cognitive Extension. Empirical Musicology Review, v. 9, n. 3-4, p. 193-202, 2014.

MANNONE, Maria. Have Fun with Math and Music! In: MONTIEL, Mariana, GOMEZ-MARTIN, Francisco, AGUSTÍN-AQUINO, Octavio A. (Eds.). International Conference on Mathematics and Computation in Music. Cham: Springer, 2019. p. 379-382.

MANTHEI, Mike, KELLY, Steve N. Effects of Popular and Classical Background Music on Math Test Scores of Undergraduate Students. Research Perspectives in Music Education, v. 6, n. 1, p. 38-42, 1999.

MAYES, Michelle. Music and Math Curricula for Second-grade Students: An Action Research Study. [PhD dissertation] Minneapolis: Capella University, 2018. 24 p.

MAZZOLA, Guerino. Mathematical Music Theory and the Musical Math Game-Two Creative Ontological Switches. In AGUSTINAQUINO, Octavio A., LLUIS-PUEBLA, Emilio, MONTIEL, Mariana (Eds.). International Conference on Mathematics and Computation in Music. Cham: Springer, 2017. p. 201-212.

MCDONEL, Jennifer S. Exploring Learning Connections between Music and Mathematics in Early Childhood. Bulletin of the Council for Research in Music Education, v. 203, p. 45-62, 2015.

MIENDLARZEWSKA, Ewa Aurelia, TROST, Wiebke Johanna. How musical training affects cognitive development: Rhythm, reward and other modulating variables. Frontiers in Neuroscience, v. 7, p. 279, 2013. MONTIEL, Mariana, GÓMEZ, Francisco. Music in the pedagogy of mathematics. Journal of Mathematics and Music, v. 8, n. 2, p. 151-166, 2014. 
The Possible Relationship between Mathematical Skills and Vocal Performance Wanli Hu

PERGER, Pamela, MAJOR, Karen, TRINICK, Robyn. Adding To, Not Taking Away: Mathematics and Music in the Primary Classroom. Teachers and Curriculum, v. 18, n. 1, p. 19-25, 2018.

RICKARD, Nikki S., BAMBRICK, Caroline J., GILL, Anneliese. Absence of widespread psychosocial and cognitive effects of school-based music instruction in 10-13-year-old students. International Journal of Music Education, v. 30, p. 57-78, 2012.

ROA, Eric Roldán, ROA, Érika Roldán, CHOUNTA, Irene-Angelica. Learning Music and Math, Together as One: Towards a Collaborative Approach for Practicing Math Skills with Music. In: NOLTE, Alexander, ALVAREZ, Claudio, HISHIYAMA, Reiko, CHOUNTA, Irene-Angelica, RODRÍGUEZ-TRIANA, Maria Jesus, INOUE, Tomoo (Eds). International Conference on Collaboration Technologies and Social Computing. Cham: Springer, 2020. p. 143-156.

SALA, Giovanni, GOBET, Fernand. When the music's over. Does music skill transfer to children's and young adolescents' cognitive and academic skills? A meta-analysis. Educational Research Review, v. 20, p. 55-67, 2017.

SHCHEDRINA, Elena, GALKINA, Elena, PETUNINA, Irina, LUSHKOV, Richard. Integration of Mobile Learning into Complex ProblemSolving Processes During STEM Education. International journal of interactive mobile technologies, v. 14, n. 21, pp. 19-37, 2020.

SCHELLENBERG, Glenn E. Music and non-musical abilities. In: MCPHERSON, Gary E. (Ed). The Child as Musician: A handbook of musical development. Oxford University Press, 2016. Chapter 8. SWAMINATHAN, Swathi, SCHELLENBERG, Glenn E. Musical Competence is predicted by Music Training, Cognitive Abilities, and Personality. Scientific Reports, v. 8, p. 9223, 2018.

TISDELL, Christopher C. An Arts-Integrated Approach to Learning Mathematics through Music: A Case Study of the Song 'e is a Magic Number'. International Journal of Innovation in Science and Mathematics Education, v. 27, n. 7, p. 46-61, 2019. 
The Possible Relationship between Mathematical Skills and Vocal Performance Wanli Hu

TŠUIKINA Natalia V., BUSURINA Ekaterina V. Linguocreative nominative realia, innovations, and Russian as a foreign language. The Education and science journal, v. 22, n. 4, p. 110-130, 2020. VAUGHN, Kathryn. Music and mathematics: Modest support for the oft-claimed relationship. Journal of aesthetic education, v. 34, n. 3/4, p. 149-166, 2000.

WEINBERGER, Norman M. The Music in Our Minds. Educational Leadership, v. 56, n. 3, p. 36-40, 1998.

WINTER, Heather Nicole. The Link between music lessons and IQ in Children. American Music Teacher, v. 66, n. 2, p. 14-18, 2016.

\section{Publisher}

Federal University of Goiás. School of Music and Performing Arts. Graduate Program in Music. Publication in the Portal of Periodicals UFG.

The ideas expressed in this article are the responsibility of their authors, and do not necessarily represent the opinion of the editors or the university. 